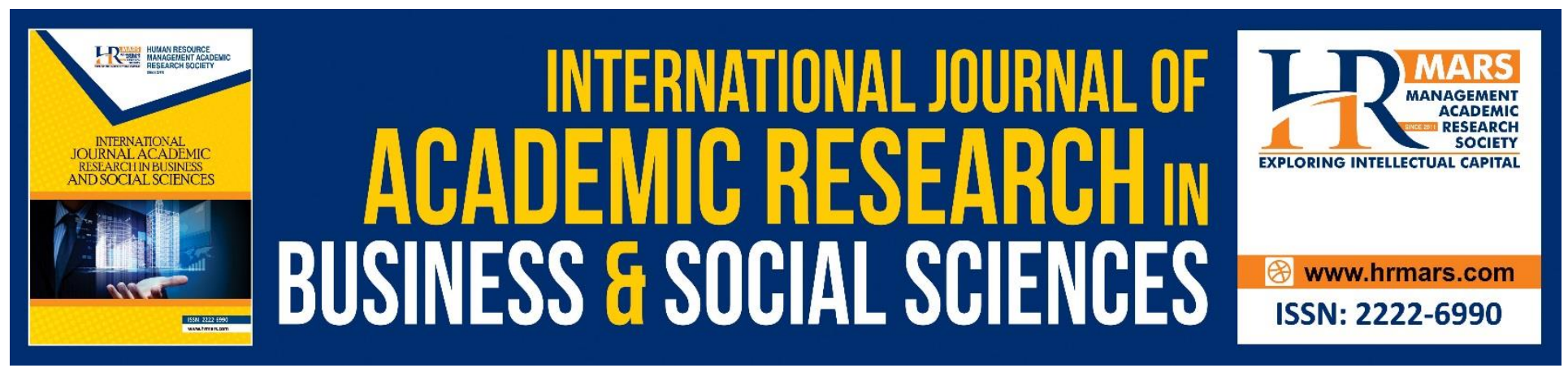

\title{
Work Culture and Turnover Intention: A Case of Restaurant Employees in Putrajaya, Malaysia
}

Hazrina Ghazali and Nurul Samhana Samsul Asmawi

To Link this Article: http://dx.doi.org/10.6007/IJARBSS/v10-i10/8276

DOI:10.6007/IJARBSS/v10-i10/8276

Received: 08 August 2020, Revised: 29 September 2020, Accepted: 28 September 2020

Published Online: 24 October 2020

In-Text Citation: (Ghazali \& Asmawi, 2020)

To Cite this Article: Ghazali, H., \& Asmawi, N. S. S. (2020). Work Culture and Turnover Intention: A Case of Restaurant Employees in Putrajaya, Malaysia. International Journal of Academic Research in Business and Social Sciences, 10(10), 1159-1177.

Copyright: (c) 2020 The Author(s)

Published by Human Resource Management Academic Research Society (www.hrmars.com)

This article is published under the Creative Commons Attribution (CC BY 4.0) license. Anyone may reproduce, distribute, translate and create derivative works of this article (for both commercial and non-commercial purposes), subject to full attribution to the original publication and authors. The full terms of this license may be seen at: http://creativecommons.org/licences/by/4.0/legalcode

Vol. 10, No. 10, 2020, Pg. 1159 - 1177

http://hrmars.com/index.php/pages/detail/IJARBSS

JOURNAL HOMEPAGE

Full Terms \& Conditions of access and use can be found at http://hrmars.com/index.php/pages/detail/publication-ethics 


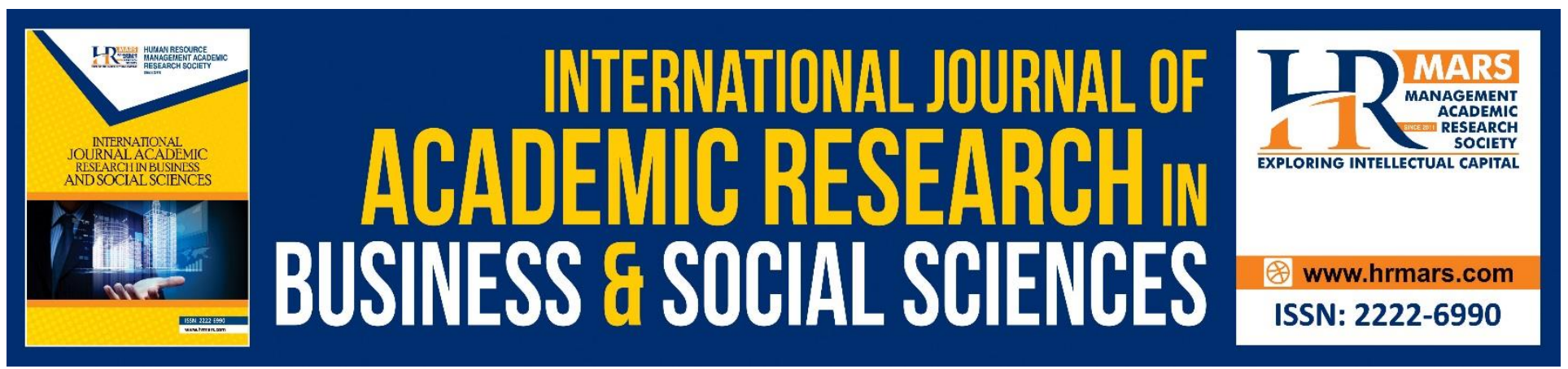

\title{
Work Culture and Turnover Intention: A Case of Restaurant Employees in Putrajaya, Malaysia
}

\author{
Hazrina Ghazali and Nurul Samhana Samsul Asmawi \\ Department of Food Service and Management, Faculty of Food Science and Technology, Universiti \\ Putra Malaysia, Serdang Selangor Malaysia
}

\begin{abstract}
The growth of restaurants industry in Malaysia also reflect the continuous growth of employees in this industry. Having many employees at workplace is parallel with salary and benefits that employers need to provide to their employees. On the other hands, to retain employees at workplace quite challenging because employees may quit due to many reasons. The purpose of this study is to examine how work culture influence turnover intention among employees in restaurant industry particularly casual dining-typed restaurants. After reviewing past literature, three independent variables were used in this study that are: consensual culture, hierarchical culture and developmental culture. This study used quantitative method and survey research design approach. A total of 210 respondents were distributed to employees who were currently working in selected casual dining restaurants at the largest mall in Southern Klang Valley. After data screening and checking, 165 valid responses were returned and analyzed by using SPSS version 23. Based on the results obtained from Pearson Correlation, result found that all three variables had weak association with turnover intention. All variables were found to be weak correlated. Hierarchical culture found to be weak positively correlated $r=.141, p=.036$. Similarly, Consensual culture also had weak positive relationship with turnover intention $r=.055, p=.248$ whereas developmental culture had negative relationship with $r=-.122, p=.060$. Additionally results also showed that majority of the employees disagreed that work culture in restaurants they worked for influenced their intention to leave a job. Next, comparing all the independent variables, developmental work culture had the highest mean score with 4.0370. Moreover, majority disagreed that they find their job easy when there is no leader assist with their job. While, another majority agreed that they felt sad when superior did not listen to their opinion. This statements indicated positive work culture has been practicing at casual dining restaurants. Findings from this study hoped to help managers and casual dining restaurant operator to highlight those work culture so that more positive environment can be sustained in this restaurant.

Keywords: Consensual Culture, Hierarchical Culture, Developmental Culture, Turnover Intention, Casual Dining Restaurants, Putrajaya
\end{abstract}

\section{Introduction}

Economic growth in Malaysia has an impact on the growth of casual dining restaurant which between 2008 and 2012, casual dining restaurants registered an annual growth rate of 3.3\% to reach sales of US\$3.4 billion, making it the largest category within Malaysian consumer foodservice. Even stronger 
INTERNATIONAL JOURNAL OF ACADEMIC RESEARCH IN BUSINESS AND SOCIAL SCIENCES Vol. 10, No. 10, 2020, E-ISSN: 2222-6990 @ 2020 HRMARS

growth is expected over the 2013-2017 forecast period, with a CAGR of 5.4\% to reach anticipated sales of US\$4.4 billion in 2017 (Market Access Secretariat Global Analysis Report, 2014). According to The Star Online (2017), there was an 11.2\% annual increase in economic census of food and beverage services compared to annual growth of $12.2 \%$ or a total of RM29.1bil since 2010 . More people were employed in the sector with the number of persons engaged in food and beverage services growing $6.7 \%$ annually to 891,616 persons.

Hence, due to the demand of the market needs, restaurants and food service industry have created a huge job opportunity from front-of-the-house (FTH) to back-of-the-house (BTH) in this industry. In casual dining restaurant, for the FTH's employees, they have the responsibility to serve the guest directly. The position includes the managers, assistant managers, host/hostess, bar tender, service crew, and cashier. While, at the BTH, the employees work outside from the customer's sight. The position includes executive chef, store manager, sous chef, kitchen helper, purchaser and etc. There also have the entry-level position where the position does not required experience from the field of the industry and they are cashier, host/hostess, busser, dishwasher, prep cook and quick-service counter server (Jones, 2014).

However, in reality, this industry always facing problems in retaining their employees. There are several factors contributed to this scenario. Based on previous studies, turnover rate issues among employees are the top topic that attracts scholars' attention to understand more factors contributed to high number of turnover rate among employees in different industries. According to Malaysian Employers Federation (2011), non-manufacturing sector has the highest annual average turnover and $32.4 \%$ the contribution was from hotel and restaurant industry. In 2015, Malaysia recorded the second highest involuntary turnover rate at $6.0 \%$ and third highest voluntary turnover rate at $9.5 \%$ in South East Asia countries (HR in Asia, 2015).

This study emphasize on relationship of culture with turnover intention. Turnover culture referred to the acceptance of turnover as part of the work- group norm within workforce which a normative belief is held by employees that turnover behavior is quite appropriate (Iverson, 1997). Different types of culture give different direct effects on job satisfaction and turnover intention, in fact, among different types of culture, several studies support that more positive culture (e.g. consensual culture) appears to increase satisfaction, and thus, to lower turnover intention (Kim, 2009). In addition, Kim, (2009) states that the transformation toward culture of fostering respect, establishing a new team relationship, and developing leadership for the managers was successful in both improving staff satisfaction and reducing turnover intention, while to support the statement, the finding of this study suggest that rational culture have the importance in work efficiency, clear and detailed work manual, organizational structure of achieving the organization goals and strategies, teamwork and interdepartmental cooperation is suitable for improving job satisfaction.

Coyne and Ong (2007) found that there is lack of evidence show that the turnover intentions have the relationship with culture. In addition, Koys (2001) have stated that there is no evidence to claim that the organizational citizenship behaviour can influence turnover rate and employees' performance and Scotter (2000) found that work performance and turnover has the negative relationship. In contrast, finding from previous study in Korea, consensual culture had highest impact 
on turnover intention than other culture types, and the effect of job satisfaction as a mediator on turnover intention was statistically significant (Kim, 2009). While, other researcher found that a person who is not too satisfied with their job is about 12.6 percentage points more likely to move from one level of turnover intention to the next level, compared to someone who is somewhat satisfied with their job and the relationship between job satisfaction and employee turnover intention is moderated by level of satisfaction with workplace culture (Medina, 2012). Therefore, the purpose of this study is to measure the relationship of work culture towards turnover intention among employees in casual dining restaurant.

\section{Research Objectives}

The general objective of this study was to identify how work culture can influence turnover intention among employees in casual dining restaurant. Hence, the specific objectives of this study are:

1. To determine variables of work culture that can lead to turnover intention and to measure the relationships between work cultures and turnover intention among employees of casual dining restaurant.

2. To determine the most influential work culture variables that influence employees' behaviour towards intention to leave job in casual dining restaurant.

3. To identify demographic profiles that affect employees' intention to leave their position in casual dining restaurants.

\section{Literature Review Work Culture}

Culture is the behaviour that results when a group arrives at a set of - generally unspoken and unwritten - rules for working together and its powerful element that shapes work enjoyment, work relationships, and work processes (Heathfield, 2016). An organization with a strong culture has ability to conduct its employees, which should help them, accomplish their missions and goals. A previous study done by Medina (2012) had found that there was a moderate relationship between employees turnover intention with workplace culture. Each unit increase in high cultural satisfaction has bigger decrease in turnover intention compared to employees with low cultural satisfaction (Medina, 2012). This study is done to explore the relationship between job satisfaction and employee turnover intention in the context of organizational culture where the data was used form Quality of Work Life (QWL) module and a sub-section of the General Social Survey (GSS). The finding of this study confirmed the research hypothesis where employees with high workplace cultural satisfaction have lower turnover intention compared to employees with low workplace cultural satisfaction.

This can be supported by previous research study, Bartlett (2002) has reported that the application of organizational culture fit to predict employee attitudes and intentions in organizations has been largely unexplored. This study was an initial attempt to investigate how organizational culture, individual values, and the match between them contribute to the explanation of variance in job satisfaction, intent to quit, and willingness to recommend the organization in a broad sample of organizations. Person-organization fit scores are shown to explain significant outcome variance. This survey study was measured by using questionnaire distribute to 182 of employees that employed in 
INTERNATIONAL JOURNAL OF ACADEMIC RESEARCH IN BUSINESS AND SOCIAL SCIENCES Vol. 10, No. 10, 2020, E-ISSN: 2222-6990 @ 2020 HRMARS

the organization (Bartlett, 2002). The finding explained that organizational culture perceived fit slightly more variance than perceived culture.

\section{Hierarchical Culture}

Hierarchy culture is a workplace with formalized and structured procedures which govern what people want to do and leaders see themselves as being highly capable coordinators and organizers (Tseng, 2011). The role and nature of hierarchy has been widely debated in recent decades, not least in terms of its positive and negative effect on organizational success and employee motivation. Those who are skeptical of hierarchy point out its connection to oppression and injustice, the lack of discretion, initiative, and flexibility, and the fact that hierarchy tends to be perceived as a demotivating force in the organization (Alvesson, 2015). According to Alvesson (2015), translation is the second vertical-horizontal dynamic and it is a category that describes how hierarchy may be constructed when management is engaged in the operative work process. Thus, the effect of managerial involvement is thus largely dependent on how it is made sense of and effectuated by employees who perform the actual work (Alvesson, 2015). Reviews from previous study have shown the relationship between leadership in hierarchical culture of the workplace have the negative and positive correlation with turnover intention among employees. Based on previous study conducted by Kim (2009) in Korea, hierarchical culture had significant and positive associations with turnover intention. The purpose of this study back then is to examine how different work culture is associated with job satisfaction and turnover intention. The finding from this study explained that hierarchical culture have effect on turnover intention with correlation value, $r=0.087$ compare with other three work culture. However, the previous study done by Kim (2004), found that consensual, rational and developmental have greater effect job satisfaction and organizational commitment than hierarchical culture.

\section{Consensual Culture}

A consensual value is focused on loyalty, tradition and internal control mechanisms of the organisation (Atiku, 2014). Schaufelli and Bakker (2004) found that engaged employees are more bounded on the organization and their intention to leave is lower. In other words, they are more loyal to the organization. This can happen because employees who have strong employee engagement usually will get positive experience and have positive image about their organization. In Suliyanto (2012) study has stated that employee engagement has effect on employee loyalty and Shuck (2011) highlighted that engaged employees have stronger relation with the organization and their intention to leave is less.

Employee engagement is defined as a degree to which extent an employee would be emotionally and intellectually committed to an organization or group (Lockwood 2007). Employee engagement is believed to have positive impact on the organization and becomes one of the key factors to the success of an organization. Strong employee engagement will result in satisfying performance from the employees. Employees who have strong engagement with the organization where they work will be willing to work harder than the others. High employee engagement level to the organization is believed to increase the talents and employee's individual performance which in turn can have a positive impact on the organization performance (Margaretha and Saragih 2008). A supporting 
INTERNATIONAL JOURNAL OF ACADEMIC RESEARCH IN BUSINESS AND SOCIAL SCIENCES Vol. 10, No. 10, 2020, E-ISSN: 2222-6990 @ 2020 HRMARS

culture in friendly work environment will really help to create employee engagement (Suliyanto, 2012).

Besides, ethical value can be defined as consensual culture in organization. Based on previous study done by Jung et al (2010), ethical value in the foodservice industry had a significant, positive effect on person-organization fit and turnover intention. Ethical value could lower the employee's turnover intent, if an individual recognized the fitness between his or her beliefs and the organization. This finding supported earlier work, Wheeler et al (2007), which suggested that any inconsistency between individual and organization values leads to high turnover rates. Conversely, an employee's person-organization fit reduces his or her turnover intent. Meanwhile, finding from previous study done by Maclntosh (2010), the cultural dimensions of atmosphere, formalization, and serviceprograms impacted job satisfaction which further impacted intention to leave the organization while connectedness influenced intention to leave directly.

\section{Developmental Culture}

High-performing organizations recognize that their success hinges on the capabilities of their employees and a "developmental" alternative to the talent war where organization are providing more generous employee benefits, for example, more high-spirited work culture such as interests in environmental sustainability, contributions to the local communities in which companies work, worker ownership, and other contemporary forms of conscious capitalism (Kegan, 2014). According to Kegan (2014), all employees in The Deliberately Developmental Organization programme are expected to contribute to the shaping of the culture, to step forward at any time to improve how the organization does its work where everyone is expected both to embody the culture and to strengthen it by participating continuously and collectively in the redesign of the organization's structures and routines. Organizational developmental professionals help their employees to improve career satisfaction, organizational commitment and to decrease turnover intention through establishing positive organizational learning culture and considering managerial support and employees' differences (Joo, 2010). According to Joo (2010), organizational learning culture, developmental feedback, and learning goal orientation are the significant predictors of turnover intention indirectly. The turnover of employees will be decreased by enhancing organizational learning culture and by considering goal orientation.Supervisor developmental feedback provides valuable information to employees and enables the employees to learn, develop, and make improvements on the job (Zhou, 2003) and it also plays a motivational role because it allows employees to experience positive feelings and connections about themselves and the organization. "Learning Goal Orientation" is refers to a desire to increase one's competence by developing new skills and mastering new situations in the organization (Joo, 2010). Individuals with high-learning goal orientation focus on increasing their learning and or task competence, seeking challenges, and persisting in the case of failure. This study done by Joo (2013) found that a personal factor (i.e. goal orientation) and contextual factors (i.e. organizational learning culture and developmental feedback) contributed to career satisfaction and organizational commitment, which, in turn, affected turnover intention. Regarding goal orientation, employees who are learning goal-oriented people are likely to have a stronger emotional attachment, such as a stronger acceptance of the organization's goals and values, a higher willingness to exert effort for the organization, and a stronger desire to maintain membership in the organization, replicating previous research (Maurer, 2002). 
INTERNATIONAL JOURNAL OF ACADEMIC RESEARCH IN BUSINESS AND SOCIAL SCIENCES Vol. 10, No. 10, 2020, E-ISSN: 2222-6990 @ 2020 HRMARS

According to Benjamin (2012), found that human resource developmental climate has significant relationship with volunteering turnover intention. This study has done in Kigali, Rwanda and the purpose of the study was to examine the relationships among human resource development climate (HRDC), organizational citizenship behaviour (OCB) and voluntary turnover intentions (VTI). Human Resource Development (HRD) is not just about employee training and development but it consists of all activities relating to training, career and organization development where it deliberate organizational or individual undertakings aimed at enhancing the skills, knowledge, ability and other attributes of an employee for effectiveness in current job demands and anticipated future challenges (Benjamin, 2012). Besides, study done by Zekeriya (2013) from Pakistan has found that the result from his study indicate employee's turnover intention is predicted by employee development perceptions. When organization provides training to its employees, it helps them in their career development which they want and need. Employees' sense of advancement and skills lead to increase productivity for them and their team where they will have more fulfilling work and are less likely to have intention to leave the job (Zekeriya, 2013).

\section{Turnover Intention}

Turnover is very difficult to predict and questions remain unanswered as to why actually the employee left. Brough and Frame (2004) defined turnover intention as an individual's estimated probability to leave his or her current organization at some point in the near future. Many scholars have attempted to answer the questions of what determines employees' intention to quit their job (Kalliath and Beck, 2001; Nasyira et al., 2014, Nasir et al, 2019). According to Perez (2008), there were determinants that cause turnover and to deduce hypothetical direction of action where several variables will be categorized into three different group; psychological, economic and demographical variables. Psychological determinants refer to the employee's mental process and behaviour, such as expectations, orientation, job satisfaction, organizational commitment, job involvement or affectivity (Perez, 2008). Economic view the employee's decision, whether he wants to leave or stay, as a result of a rational cost-benefit assessment and analyses the turnover process with more emphasis on the interplay between externally determined variables such as pay or opportunity (Perez, 2008). While, demographic variables known as personal characteristics that widely used in turnover research with two determinants were examined to have a direct impact on turnover intent such as tenure and age (Perez, 2008). The social aspect refers to the social behaviour of an employee within his organization, such as integration or relationship with other associates and low perceived financial and social aspects in the own can lead to turnover (P erez, 2008). A part from that, there was a study conduct in UK where the aims to identify key variables that influence the variability of labour turnover. The approach used in this research was a case study of a major retailer and the key data sources was an index for local competitive and labour market factors, an annual employee survey, and internal labour turnover data for each UK unit of the retailer. Environmental and organizational factors have a major influence on labour turnover. While, management behaviour as seen through operational and control variables are also of importance. "Values, trust and respect between employees" is the most important significant predictor of labour turnover (Hamer, 2007). Next, corporate value; "give support to each other" and employees' level of "development and career building satisfaction" were reported as significant predictor of labour turnover (Hamer, 2007). 
INTERNATIONAL JOURNAL OF ACADEMIC RESEARCH IN BUSINESS AND SOCIAL SCIENCES Vol. 10, No. 10, 2020, E-ISSN: 2222-6990 @ 2020 HRMARS

Figure 1: Conceptual Framework of This Study

Independent Variables

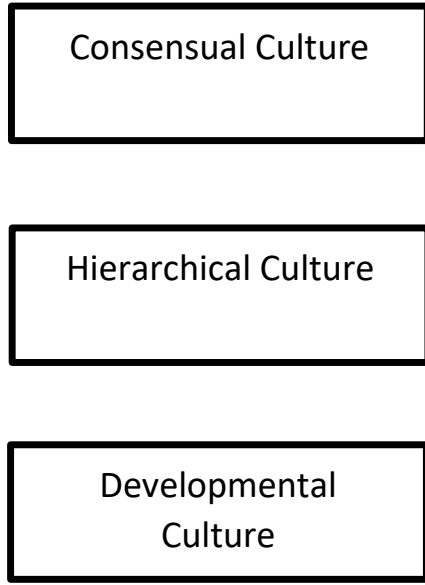

\section{Dependent Variable}

Employees' Turnover Intention

\section{Methodology}

This study employed quantitative method and this study was conducted among employees of selected casual dining restaurant at the largest mall in Southern Klang Valley. This mall known as IOI City Mall is easily accessible via major highways and public transport. Its size about 1.5 million square feet and occupied by trendy fashion brands, supermarket, cineplexes and Food \& Beverages outlets offering exquisite local and international dining experiences (IOlcity mall website, 2020). The sampling method for this study was a convenience sampling. According to Etikan (2016) the main objective of convenience sampling is to collect information from participants who are easily accessible to the researcher. A self-administered questionnaire was designed for this study. Participation of the restaurants and employees in this study was voluntary basis and a total of 210 numbers of questionnaires was distributed to 21 casual dining restaurants in IOI City Mall, Putrajaya for the data collection.

\section{Results}

\section{Demographic Profiles}

After data checking and screening, out of 210 questionnaires distributed there were only 165 of valid responses (78.6\%) obtained for further analysis. Based on table 1, the distribution of respondents consisted of 90 male respondents and 75 of female respondents with $54.5 \%$ and $45.5 \%$ respectively. In term of age group, the highest age range were between $20-29$ years old which 106 of the respondents takes $64.2 \%$ of the percentage. Then, followed by 32 respondents aged less than 20 years old (19.4\%) and 23 of them aged between $30-39$ years old (13.9\%). There was a minority age range of the respondents which only 3 participants aged 40-49 years old (1.8\%) and only 1 respondent aged above 50 years old $(0.6 \%)$. Thus, it can be concluded that majority of the respondents in this study were within young generation. Majority of respondents were Malays (70.3\%) and followed by other races.

Next, for education background, the highest proportion of the responses received was 65 of the respondents had SPM as the higher level of education background (39.4\%) and followed by 39 of 
INTERNATIONAL JOURNAL OF ACADEMIC RESEARCH IN BUSINESS AND SOCIAL SCIENCES Vol. 10, No. 10, 2020, E-ISSN: 2222-6990 @ 2020 HRMARS

the respondents had Diploma/ Certificate background (23.6\%) which slightly higher than Bachelor Degree (22.4\%) with 37 of participants. Besides, 11 respondents hold Master/ PhD (6.7\%) while 6 others (3.6\%) had different certificate. Furthermore, for work position composition, 78 of the respondents were waiter / waitress (47.3\%). There were 27 kitchen crew (16.4\%) and 26 respondents hold the assistant manager position (15.8\%). 12 respondents were the leader crew (7.3\%) and 10 were worked as cashier (6.1\%). In term of work position status, of 165 respondents responded in this survey, majority worked as full time employees (63.6\%) with 105 of the participants. Then followed by 44 respondents worked as part timer (26.7\%), 8 of contract worker (4.8\%), 7 of hourly worker $(4.2 \%)$ and 1 as others position (0.6\%). Another questions asked in demographic section was years of working in current restaurants and working experience in the industry. In term of work duration, it is found that 58 of the respondents were working less than 6 months (35.2\%) and just barely different from 47 of respondents who work less than 1 year (28.5\%). Some proportion also shows that 33 respondents already work from 1 to 3 years (20.0\%). Only 27 of the respondents worked or more than 3 years (16.4\%) in the selected casual dining restaurants. Last but not least, there were 58 of the respondents who had less than 6 months' work experience (35.2\%) in this restaurant industry. For the department category, majority of the respondents were form front of the house (104 of the participants) and 61 respondents were from back of the house department.

Table 1: Summary of Demographic Profile of Respondent

\begin{tabular}{llcc}
\hline Variables & Category & Frequency (N) & Percentage (\%) \\
\hline Gender & Male & 90 & 54.5 \\
\multirow{4}{*}{ Age } & Female & 75 & 45.5 \\
& Less Than 20 & 32 & \\
& $20-29$ & 106 & 19.4 \\
& $30-39$ & 23 & 64.2 \\
& $40-49$ & 3 & 13.9 \\
Race & Above 50 & 1 & 1.8 \\
& Malay & & 0.6 \\
& Chinese & 117 & \\
& Indian & 8 & 70.3 \\
Education & Other & 7 & 4.8 \\
& & 34 & 4.2 \\
& PMR & 7 & 20.6 \\
& SPM & 65 & 4.2 \\
& Diploma / Certificate & 39 & 39.4 \\
& Bachelor Degree & 37 & 23.6 \\
& Master / PhD & 11 & 22.4 \\
& Other & 6 & 6.7 \\
\multirow{5}{*}{ Work Position } & & & 3.6 \\
& Restaurant Manager & 6 & 3.6 \\
& Cashier & 10 & 6.1 \\
& Leader Crew & 12 & 7.3
\end{tabular}


INTERNATIONAL JOURNAL OF ACADEMIC RESEARCH IN BUSINESS AND SOCIAL SCIENCES Vol. 10, No. 10, 2020, E-ISSN: 2222-6990 @ 2020 HRMARS

$\begin{array}{lcc}\text { Kitchen Crew } & 27 & 16.4 \\ \text { Assistant Manager } & 26 & 15.8 \\ \text { Waiter / Waitress } & 78 & 47.3 \\ \text { Chef / Kitchen Head } & 4 & 2.4 \\ \text { Other } & 2 & 1.2 \\ & & \\ \text { Part Time } & 44 & 26.7 \\ \text { Full Time } & 105 & 63.6 \\ \text { Hourly } & 7 & 4.2 \\ \text { Contract } & 8 & 4.8 \\ \text { Other } & 1 & 0.6\end{array}$

\begin{tabular}{llcc} 
Position Status & Part Time & 44 & 26.7 \\
& Full Time & 105 & 63.6 \\
& Hourly & 7 & 4.2 \\
& Contract & 8 & 4.8 \\
& Other & 1 & 0.6 \\
Work Duration & Less Than 6 Months & 58 & 35.2 \\
& Less Than 1 Year & 47 & 28.5 \\
& 1 - 3 Years & 33 & 20.0 \\
More Than 3 Years & 27 & 16.4 \\
Working Experience & & 35.2 \\
& Less Than 6 Months & 58 & 28.5 \\
& Less Than 1 Year & 39 & 20.0 \\
& 1 - 3 Years & 32 & 16.4 \\
More Than 3 Years & 36 & 37 \\
Department & Back Of The House & 61 & 63 \\
\hline
\end{tabular}

Source: Developed from SPSS version 23

Table 2 shows the summary of descriptive analysis of all the variables in this study. The dependent variable was the turnover intention among employees of casual dining restaurant, while the independent variables of this study were consensual work culture, hierarchical work culture and developmental work culture. Table 2 shows mean and standard deviation of turnover intention was 2.8505 and 0.89840 respectively. This result explained that employees of selected casual dining restaurant in IOI City Mall, Putrajaya had less intention to leave their current job. Next, comparing all the independent variables shown above, developmental work culture stated the highest mean score with 4.0370. It strongly shows employees of the casual dining restaurants practiced and acknowledged the implementation of this culture in their work environment. On the other hand, mean score for consensual work culture was 3.8438 while the mean score for hierarchical work culture was 3.3879. Form the result implied that both consensual and hierarchical work cultures were in the range towards agreement level on the implementation and practices of those culture at workplace. 
INTERNATIONAL JOURNAL OF ACADEMIC RESEARCH IN BUSINESS AND SOCIAL SCIENCES Vol. 10, No. 10, 2020, E-ISSN: 2222-6990 @ 2020 HRMARS

Table 2: Descriptive Analysis of All Variables

\begin{tabular}{lccc}
\hline Variables & Frequency $(\mathrm{N})$ & Mean & Std. Deviation \\
\hline $\begin{array}{l}\text { Dependent Variable } \\
\text { Turnover Intention }\end{array}$ & 165 & 2.8505 & 0.89840 \\
Independent Variable & & & \\
Consensual Culture & 165 & 3.8438 & 0.86825 \\
Hierarchical Culture & 165 & 3.3879 & 0.82896 \\
Developmental Culture & 165 & 4.0370 & 0.87000 \\
\hline
\end{tabular}

Note: 1= Strongly disagree, 2=Disagree, 3=Neutral, 4=Agree, 5=Strongly agree

Furthermore, Table 3 below discussed the level of agreement between work culture and turnover intention. From the analysis, it revealed positive work culture has been practising in the restaurants. For example, majority of the employees (44.4\%) disagreed that work culture in restaurants they worked for influenced their intention to leave a job. Majority of respondents also disagreed (43.8\%) that they find their job easy when there is no leader assist with their job. The respondents agreed that they felt sad when superior did not listen to their opinion (37.7\%). 
INTERNATIONAL JOURNAL OF ACADEMIC RESEARCH IN BUSINESS AND SOCIAL SCIENCES Vol. 10, No. 10, 2020, E-ISSN: 2222-6990 @ 2020 HRMARS

Table 3: Frequency Analysis on Agreement Level between Work Culture and Turnover Intention Note: 1= Strongly disagree, 2=Disagree, 3=Neutral, 4=Agree, 5=Strongly agree

\begin{tabular}{|c|c|c|c|}
\hline Statement & Agree & Neutral & Disagree \\
\hline $\begin{array}{l}\text { Work culture in this } \\
\text { restaurant influence } \\
\text { my intention to leave } \\
\text { my job }\end{array}$ & $18.6 \%$ & $37.1 \%$ & $44.4 \%$ \\
\hline $\begin{array}{l}\text { I find my job is easy to } \\
\text { do when there is no } \\
\text { leader assist me with } \\
\text { my work }\end{array}$ & $28.2 \%$ & $28.1 \%$ & $43.8 \%$ \\
\hline $\begin{array}{l}\text { I feel sad when my } \\
\text { superior do not listen } \\
\text { to my opinion }\end{array}$ & $37.7 \%$ & $34.1 \%$ & $28.2 \%$ \\
\hline $\begin{array}{l}\text { I don't care with } \\
\text { company goals } \\
\text { because I won't last } \\
\text { with this job }\end{array}$ & $19.8 \%$ & $26.9 \%$ & $53.2 \%$ \\
\hline $\begin{array}{l}\text { My colleagues are } \\
\text { easy to make enemies }\end{array}$ & $20.2 \%$ & $26.3 \%$ & $53.2 \%$ \\
\hline $\begin{array}{l}\text { I do not believe with } \\
\text { my colleagues' } \\
\text { credibility when } \\
\text { performing task }\end{array}$ & $21.0 \%$ & $26.4 \%$ & $54.5 \%$ \\
\hline
\end{tabular}

Additionally, Pearson correlation analysis was conducted to determine the strength and direction of a linear relationship between variables. Table 4 shows correlation between three variables in this study with turnover intention. All variables were found to be weak correlated. Hierarchical culture found to be weak positively correlated $r=.141, p=.036$. Similarly, Consensual culture also had weak positive relationship with turnover intention $r=.055, p=.248$ whereas developmental culture had negative relationship with $r=-.122, p=.060$. Next, result also indicate the strength of association between the consensual and hierarchical work culture was weak $(r=0.355)$, and that the correlation coefficient was very highly significantly different from zero $(P<0.001)$. Next, there was moderate relationship between consensual and developmental work culture $(r=0.615)$, and that the correlation coefficient was significant $(P<0.001)$. Apart from that, the strength of association between the developmental and hierarchical work culture was weak $(r=0.311)$, and that the correlation coefficient was significantly $(P<0.001)$. Both variables were positively associated and only $31.1 \%$ of developmental work culture explained by hierarchical work culture. 
INTERNATIONAL JOURNAL OF ACADEMIC RESEARCH IN BUSINESS AND SOCIAL SCIENCES Vol. 10 , No. 10, 2020, E-ISSN: 2222-6990 @ 2020 HRMARS

Table 4: The Pearson Correlation Analysis between variables and Turnover Intention

\begin{tabular}{llllll}
\hline & & \multicolumn{3}{l}{ Development } \\
& & Turnover & al & Consensual & Hierarchical \\
\hline Turnover & Pearson Correlation & 1 & -.122 & .055 & $.141^{*}$ \\
Intention & Sig. (1-tailed) & & .060 & .241 & .036 \\
& $\mathrm{~N}$ & 165 & 165 & 165 & 165 \\
Developmental & Pearson Correlation & -.122 & 1 & $.615^{* *}$ & $.311^{* *}$ \\
& Sig. (1-tailed) & .060 & & .000 & .000 \\
& $\mathrm{~N}$ & 165 & 165 & 165 & 165 \\
Consensual & Pearson Correlation & .055 & $.615^{* *}$ & 1 & $.355^{* *}$ \\
& Sig. (1-tailed) & .241 & .000 & & .000 \\
& $\mathrm{~N}$ & 165 & 165 & 165 & 165 \\
Hierarchical & Pearson Correlation & $.141^{*}$ & $.311^{* *}$ & $.355^{* *}$ & 1 \\
& Sig. (1-tailed) & .036 & .000 & .000 & \\
& $\mathrm{~N}$ & 165 & 165 & 165 & 165 \\
\hline
\end{tabular}

*. Correlation is significant at the 0.05 level (1-tailed).

**. Correlation is significant at the 0.01 level (1-tailed).

Table 5 below represents the multiple linear regression data analysis between dependent variable and independent variables of this study. Based on table above surprisingly only $6.6 \%$ of variance in casual dining restaurants' employees was explained by consensual, hierarchical, and developmental of work culture at their work places. It means that other $93.4 \%$ was explain and predicted by other factors. This result suggest those variables were not the best influenced or indicator on employees' turnover intention. One possible managerial implication from this is that the practise and implementation of work culture in the restaurant was considered good and positive culture.

Table 5: Multiple Linear Regression Analysis between Variables

\begin{tabular}{ccccc} 
Model & R & R Square & Adjusted R Square & $\begin{array}{c}\text { Std. Error of the } \\
\text { Estimate }\end{array}$ \\
\hline 1 & $0.257^{\mathrm{a}}$ & 0.066 & 0.049 & 0.87623 \\
\hline & b. & Predictors: (Constant) & & \\
\hline
\end{tabular}
a.
b. Predictors: (Constant), Developmental_1, Hierachical_1, Consensual_1 
INTERNATIONAL JOURNAL OF ACADEMIC RESEARCH IN BUSINESS AND SOCIAL SCIENCES Vol. 10, No. 10, 2020, E-ISSN: 2222-6990 @ 2020 HRMARS

Table 6: Equation Between Variables

\begin{tabular}{lcc}
\hline Model & \multicolumn{2}{c}{ Unstandardized Coefficients } \\
\cline { 2 - 3 } & B & Std. Error \\
\hline (Constant) & 2.726 & \\
Consensual_1 & 0.170 & 0.102 \\
Hierachical_1 & 0.182 & 0.089 \\
Developmental_1 & -0.284 & 0.101 \\
\hline
\end{tabular}

a. Dependent Variable: Turnover Intention

Table 6 shows all the output from multiple regression analysis of all the independents variables. The three independents variables were consensual, hierarchical and developmental work culture. Based on the table, for every 1 unit increases in consensual work culture, turnover of employees will increase by 0.170 . While, for every 1 unit increases in hierarchical work culture, turnover of employees will increase by 0.182 . And, for every 1 unit increases Multiple Linear Regression analysis was conducted to determine the relationship between work culture and turnover intention of employees in casual dining restaurants. According to the details hierarchical work culture was the highest influenced on employees' turnover intention in casual dining restaurants, where the value of Beta is 0.168 , followed by consensual work culture where the beta value is 0.165 and the least is developmental work culture, beta value is -0.275 . Thus, the highest influence variance had stronger relationship with the dependent variable. However, even hierarchical work culture was the highest influenced on employees' turnover intention in casual dining restaurants, it did not influenced employees' turnover intention significantly, because the number of $t=0.928$ and $p>0.1$. While, consensual work culture was significantly influenced employees' turnover intention, $t=1.990$ and $p<0.05$. Developmental work culture also shown the same pattern where it was significantly influenced employees' turnover intention with the $t=-2.540$ and $p<0.05$. This indicated that consensual work culture had the highest significant among three variables.

\section{Discussion}

\section{Relationship of Work Culture towards Turnover Intention}

The main objectives of this study was to identify the relationship of work culture on turnover intention in casual dining restaurant. Despite an increasing amount of research on work culture very few have clearly highlighted work culture practised within restaurant industry. Frequency analysis and Pearson Correlation were used to identify variables of work culture induced by the restaurant that can lead to turnover intention behavioural. Based on the results obtained, it was found that all three variables had weak association with turnover intention. All variables were found to be weak correlated. Hierarchical culture found to be weak positively correlated $r=.141, p=.036$. Similarly, Consensual culture also had weak positive relationship with turnover intention $r=.055, p=.248$ whereas developmental culture had negative relationship with $r=-.122, p=.060$

With regards to descriptive analysis, it showed that majority of the employees disagreed that work culture in restaurants they worked for influenced their intention to leave a job. Moreover, majority disagreed that they find their job easy when there is no leader assist with their job. While, another majority agreed that they felt sad when superior did not listen to their opinion. This statements indicated positive work culture has been practising at casual dining restaurants. Apart 
INTERNATIONAL JOURNAL OF ACADEMIC RESEARCH IN BUSINESS AND SOCIAL SCIENCES Vol. 10, No. 10, 2020, E-ISSN: 2222-6990 @ 2020 HRMARS

from that, another pattern from the frequency analysis shows that majority of the respondents were aware about developmental culture in their work place. Majority employees were care with the organization goals because they had a thinking on being loyal with their job. On the other hand, the outcome indicated that the work culture infused in casual dining restaurant was the right consensual culture. For example, based on the questionnaires, majority of the respondents were disagree that their colleagues were easy to make enemies. Meanwhile, another majority also disagree with the statement "I don't believe with my colleagues' credibility when performing task'. This can be considered as a solid evidence to prove there was a good consensual culture practises among employees in casual dining restaurants. Result of this study parallel with Suliyanto (2012) which stated that employees engagement has effect on employee loyalty and Shuck (2011), said that engaged employees have stronger relation with the organization and their intention to leave is less. Findings of this study was different from Kim (2009) where consensual culture has greatest effect on turnover intention (path coefficients $=-0.118, p<0.01$ ).

Additionally, descriptive analysis was used to compare the mean score of each variable. Result found the highest variable with mean score 4.0370 and standard deviation 0.87000 was a developmental work culture. Meanwhile, based on the multiple regression analysis, developmental culture stated the most influential variable that influenced turnover intention (Beta value=0.284). As developmental culture decrease, the turnover intention increase. This indicated developmental work culture as the most influential variable compared to consensual and hierarchical work culture.

Meanwhile, the mean score of the turnover intention among employees was 2.8505 with standard deviation of 0.89840 . As to relate to data obtained, the lower the developmental work culture, the higher the number of turnover intention among employees of casual dining restaurants. This statement was supported by other findings from previous study where it stated employees who are strongly believe with organization's goals and values tend to give extra efforts to maintain their relationship with the organization (Maurer, 2002). Besides, study done by Zekeriya (2013) from Pakistan has found that the result from his study indicate employee's turnover intention is predicted by employee development perceptions. In addition, employees' sense of advancement and skills lead to increase productivity for them and their team where they will have more fulfilling work and are less likely to have intention to leave the job (Zekeriya, 2013).

\section{Roles of Demographic and Turnover Intention}

In this study, Independent T-Test and One-way ANOVA Analysis were used as to identify demographic determinants that affect employees' behaviour towards intention to leave their position in casual dining restaurants. Independent T-Test was used to compare the mean scores between two group sample from the population; employees gender and employees department in casual dining restaurant. Based on the result from the analysis, gender of employees did not affect employees' behaviour towards intention to leave their position in casual dining restaurants. This can be proved with the outcome from the analysis where there was no statistically significant between female employees and male employees when the significant between them was $P>0.05$. Finding of this study parallel with previous research done by Ryan, Ghazali and Mohsin (2011), which found gender did not influenced intentions to leave job.

Meanwhile, the data analysis of employees' department category, indicated that the different between employees' department did affect employees' behaviour towards intention to leave their 
INTERNATIONAL JOURNAL OF ACADEMIC RESEARCH IN BUSINESS AND SOCIAL SCIENCES Vol. 10, No. 10, 2020, E-ISSN: 2222-6990 @ 2020 HRMARS

position in casual dining restaurants. As an evidence, there was statistically significant difference between back of the house employees and front of the house employees as $p<0.05$. In this study, overall the results suggest there were no significant differences between turnover intentions with demographic variables. However, different department gave statistical difference between Front-ofthe house employees with Back-of-the-house employees. This outcome implied that turnover intention occurred between employees in casual dining restaurants influenced by employees' demographics background. Therefore, it can be concluded, employees department was the only demographics factor that affect employees' behaviour towards intention to leave their position in casual dining restaurants. From this study, it shows out of 165 respondents, 104 employees from service department (Front-of-the house) were the most who had intention to leave their job. This scenario was probably due to the lack of understanding of the work culture induced by their restaurant. This supported by previous study that claimed ethical conduct of leaders (including team leaders at functional levels in organizational setting) works as a stimulus for positive feelings among frontline employees (Zarkada, 2017).

\section{Conclusion}

Findings from this study hopefully shed light and offer recommendations to managers and restaurant operators to highlight the work culture that may influence turnover intention among employees. Once the right and positive work culture practice and implement within restaurant environment, this industry is able to retain employees and reduce the turnover intention. To create a culture of growth and profit, owners and managers in the restaurant industry should broaden their perspective on key contributors of work culture. A successful restaurant culture can drive more profits and create employees loyalty. Even though findings of this study, disclosed work culture have small association with turnover intention, but the findings might shape some direction and alert the restaurant operators on importance of work culture in the restaurant industry. Positive work culture drive a good employee's performance which in turn delivered excellent services to customers. Additionally, among three independent variables tested in this study, developmental culture was dominantly influenced the dependent variables with the highest mean score 4.037. It strongly shows employees of the casual dining restaurants practiced and acknowledged the implementation of this culture in their work environment. On the other hand, mean score for consensual work culture was 3.8438 while the mean score for hierarchical work culture was 3.3879. Form the result implied that both consensual and hierarchical work cultures were in the range towards agreement level on the implementation and practices of those culture at workplace. Demographics factors did not affect employees' turnover behavioural except for the department of the employees. Both back- of-the house and in-front- of the house department had a different believed and engagement to their organization. Overall, all objectives were achieved even some of the outcome was different from researcher prediction.

\section{Recommendation and Implication}

The researcher hopes that this study can be used as a starting point for more research on work culture in the restaurant context which there are many other perspective of study that can be interesting to look deeper into. This study only emphasis on work culture that comprised on Consensual Culture, Developmental Culture and Hierarchical Culture. It would be interesting these variables can be investigated further. Next, future research also advice to investigate other possible 
INTERNATIONAL JOURNAL OF ACADEMIC RESEARCH IN BUSINESS AND SOCIAL SCIENCES Vol. 10, No. 10, 2020, E-ISSN: 2222-6990 @ 2020 HRMARS

variables that may explain the problem obtained from this study thus may fill the study gap. It is also recommended to use other research methodology rather than using non-probability the convenience sampling and quantitative study method, so that future researcher may see things from different perspective. Besides, it is recommended for the future research to expand their research area and increase their sample size. Moreover, from the analysis and further research, human resources department may come out with training module that induce or cultivate good work culture to practice in their organization.

\section{Corresponding Author}

Associate Prof. Dr. Hazrina Ghazali

Department of Foodservice and Management Faculty of Food Science and Technology Universiti Putra Malaysia

hazrina@upm.edu.my

\section{References}

Alvesson, S. E. (2015). Understanding Hierarchy in Contemporary Work. Reinventing Hierarchy and Bureaucracy, page 113-140.

Atiku, S. O. (2014). Consensual and Entrepreneurial Culture: Insights from Organisational Culture and Human Resource Development Policy in Nigerian Banks. Mediterranean Journal of Social Sciences, Vol 5 No 20.

Joo, B. K. (2010). Career satisfaction, organizational commitment, and turnover intention: The effects of goal orientation, organizational learning culture and developmental feedback. Leadership \& Organization Development Journal, Vol. 31 Issue: 6, pp.482-500.

Bartlett, M. T. (2002). The hospitality industry culture profile: a measure of individual values, organizational culture, and person-organization fit as predictors of job satisfaction and behavioral intentions. Hospitality Management 21, 151-170.

Benjamin, A. (2012 ). Human Resource Development Climate as a Predictor of Citizenship Behaviour and Voluntary Turnover Intentions in the Banking Sector. International Business Research, Vol. 5, No. 1; January 2012.

Bonett, T. A. (2007). Job Satisfaction and Psychological Well-Being as Nonadditive Predictors of Workplace Turnover. Journal of Management, 33: 141-160.

Brough, P., \& Frame, R. (2004). Predicting Police job satisfaction, work well being and turnover intentions: The role of social support and police organizational variables. New Zealand Journal of Psychology, Vol. 18, No. 7. Pp 649-679

Chen, Y. F. R. (2014). The gendered trickle-down effect: How mid-level managers' satisfaction with senior managers' supervision affects line employee's turnover intentions. Career Development International, Vol. 19 Issue: 7, pp.836-856.

Choi, S. (2014). Effects of Organizational Culture, Self-Leadership and Empowermenton Job Satisfaction and Turnover Intention in General Hospital Nurses. J Korean Acad Nurs Adm, Vol. 20 No. 2, 206-214.

Coyne, I., \& Ong, T. (2007) Organizational citizenship behaviour and turnover intention: a crosscultural study. The International Journal of Human Resource Management, 18:6, 1085-1097 
INTERNATIONAL JOURNAL OF ACADEMIC RESEARCH IN BUSINESS AND SOCIAL SCIENCES

Vol. 10, No. 10, 2020, E-ISSN: 2222-6990 @ 2020 HRMARS

Hamer, S. B. (2007). Labour turnover in the retail industry: Predicting the role of individual, organisational and environmental factors. International Journal of Retail \& Distribution Management, Vol.35 Issue: 4, pp.289-307.

Hassanzadeh, F. R. (2013). The impact of website content dimension and e-trust on emarketingeffectiveness: The case of Iranian commercial saffron corporations. Information \& Management, 240-247.

Heathfield, S. M. (2016). the balance. Retrieved 18 November, 2017, from What Makes Up Your Company Culture?: https://www.thebalance.com/what-makes-up-your-company-culture1918816

Henneberger, A. S.-P. (2002). Analyzing Job Mobility With Job Turnover Intentions: An International Comparative Study.

HR in Asia. (2015). Key Insights to Attract, Reward and Retain Talent in Malaysia: Aon Hewitt's Views - HR in ASIA. Retrieved from http://www.hrinasia.com/recruitment/keyinsights-to-attractreward-and-retain-talent-in-malaysia-aon-hewitts-views/

Iverson, R. D., \& Deery, M. (1997). Turnover culture in hospitality industry. Human resource management journal. Vol 7, No 4. page 71-82

IOlcity mall website. (2018). https://www.ioicitymall.com.my/home/

Etikan, I. (2016). Comparison of Convenience Sampling and Purposive. American Journal of Theoretical and Applied Statistics, Vol. 5, No. 1, pp. 1-4.

Jung, H. S., Namkung, Y., \& Yoon, H. H. (2010). The effects of employees' business ethical value on person-organization fit and turnover intent in the foodservice industry. International Journal of Hospitality Management, 29(3), 538-546.

Jones, A. (2014). What are casual-dining restaurants? An in-depth overview of the US restaurant industry.

Kalliath, T. J., \& Beck, A. (2001). "Is the path to burnout and turnover paved by a lack of supervisory support: A structural equation test". New Zealand Journal of Psychology, Vol. 30, pp.72-78

Kegan, R. ( 2014). The Deliberately Developmental Organization. WAY TO GROW, 1-15.

Kim, J. S. (2009). "Do types of organizational culture matter in nurse job satisfaction and turnover intention? Leadership in Health Services, Vol. 22 Issue: 1, pp.20-38.

Koys, D. J. (2001). The Effects of Employee Satisfaction, Organizational Citizenship Behavior, and Turnover on Organizational Effectiveness: A Unit-Level, Longitudinal Study. Personnel Psychology, Vol. 54, Issue 1

Lockwood, N. R. (2007) Leveraging Employee Engagement for Competitive Advantage. Society for Human Resource Management Research Quarterly, 1, 1-12.

Maclntosh, E. W. (2010). The influence of organizational culture on job satisfaction and intention to leave. Sport Management Review, 106-117.

Margaretha, M., \& Saragih, S. (2008), 'Employee engagement: upaya peningkatan kinerja organisasi', Proceedings of the 2nd National Conference, Widya Mandala University, Surabaya.

Maurer, T. (2002). Employee learning and development orientation: toward an integrative model of involvement in continuous learning. Human Resource Development Review, vol. 1 No. 1, pp. 9-44.

Medina, E. (2012). Job Satisfaction and Employee Turnover Intention: What does Organizational Culture Have To Do With It? Master thesis. Columbia University. 
INTERNATIONAL JOURNAL OF ACADEMIC RESEARCH IN BUSINESS AND SOCIAL SCIENCES Vol. 10, No. 10, 2020, E-ISSN: 2222-6990 @ 2020 HRMARS

Nasyira, M. N., Othman, M., and Ghazali, H. (2014). Predictors of intention to stay for employees of casual dining restaurant in Klang Valley area. International Food Research Journal, 21(3): 863871.

Nasir, N. N. M., \& Ghazali, H. (2019). Predictors of Intention to Leave a Job for Employees of Casual Dining Restaurant in Klang Valley, Malaysia. International Journal of Academic Research in Business and Social Sciences, 9(5), 773-783.

Perez, M. (2008). Turnover Intent. Diploma thesis. University of Zurich. Switzerland.

Richard, F., Ghiselli, J. M. (2001). Job satisfaction, life satisfaction and turnover intent among foodservice managers. The Cornell Hotel and Restaurant Administration Quarterly, volume 42, issue 2, page 28-37.

Ryan, C., Ghazali, H. and Mohsin, A. (2011). Determinants of intention to leave a non-managerial job in the fast-food industry of West Malaysia. International Journal of Contemporary Hospitality Management, Vol. 23 No. 3, pp. 344-360.

Suliyanto, L. S. (2012). The Effects of Organizational Culture and Leadership Style toward Employee Engagement and Their Impacts toward Employee Loyalty. World Review of Business Research, Vol. 2. No. 5 Page $128-139$.

Schaufeli, W. B., and Bakker, A. B. (2008). Positive organizational behavior: engaged employees in flourishing organizations. Journal of Organizational Behaviour. Vol. 29, Issues 2. Page 147-154

Shuck, B. (2011).Four emerging perspectives of employee engagement: An integrative literature review. Human Resource Development Review, 20(10), 1-25

Scotter, J. R. V. (2000). Relationships of Task Performance and Contextual Performance with turnover, Job Satisfaction, and affective Commitment. Human Resource Management Review, Volume 10, Number 1.

Tsai, Y. (2011). Relationship between Organizational Culture, Leadership Behavior and Job Satisfaction. BMC Health Services Research, 11:98.

Tseng, S.-M. (2011). The effects of hierarchical culture on knowledge management processes. Management Research Review, Vol. 34 Issue: 5, pp.595-608.

Upasna, A., Agarwal, S. D.-B. (2012). Linking LMX, innovative work behaviour and turnover intentions: The mediating role of work engagement. Career Development International, Vol. 17 Issue: 3, pp.208-230.

Wheeler, A. R., Gallagher, V. C., Brouer, R. L., \& Sablynski, C. J. (2007). When person-organization (mis)fit and (dis)satisfaction lead to turnover. Journal of Managerial Psychology Vol. 22. No. 2, pp 203- 219.

Zarkada, A. T. R. (2017). Customer aggression and organizational turnover among service employees: The moderating role of distributive justice and organizational pride. Vol. 46 Issue: 8, pp.16721688.

Zekeriya, R. W. (2013). Employee development and turnover intention: theory validation. European Journal of Training and Development, Vol. 37 Issue: 6, pp.564-579. 